\section{Ni bind som burde vært tre?}

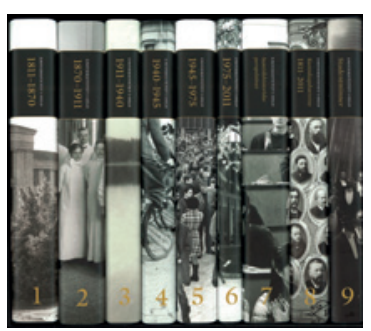

John Peter Collett, red.

\section{Universitetet i Oslo 1811-2011}

Oslo: Forum for universitetshistorie/ Unipub, 2011. Ni bind i eske.

Pris NOK 1998

ISBN 978-82-7477-548-0
Universitetet i Oslo feiret sitt 200-årsjubileum i 2011. Bursdagsbarnet fikk en prektig gave: et nibindsverk om seg selv. Det var resultatet av nesten 20 års forskning og 40 millioner kroner. Verket er på ca. 4000 sider, og i kjølvannet av denne innsatsen er det kommet nærmere 100 publikasjoner, 30 hoved- og masteroppgaver og seks doktorgrader.

Landets første universitet, som startet med sju professorer og 18 studenter, har vokst til dagens omkring 7000 ansatte og 28000 studenter. «Bokserien belyser hvordan universitetet har forandret seg gjennom 200 år, i et samspill mellom indre dynamikk og kontakten med det norske samfunn og en internasjonal omverden,» reklamerer forlaget. Og sant er vel det.

Men det må sies: Verket har fătt en behersket mottakelse. Trond Berg Eriksen skrev riktignok at det er «en uomgjengelig referanse» for alle som skal skrive om utviklingen av det norske samfunnet (1), men også at det er «en svært høflig historiefremstilling hvor det meste tas i beste mening» (2). Rune Slagstad mente at «Fraværet av en myndig faglig ledelse og en kraftfull redaksjonell hånd er påtakelig». At verket er på ni bind forkynner «for all verden at hovedstadens breddeuniversitet har est utover sine bredder. Det burde ha greid seg med tre bind» (3). Espen Søbyes anmeldelse, som gikk over to utgaver i Morgenbladet, var heller ikke egnet til å muntre opp utgiverne: «Verket preges av koseprat, og forholder seg for høflig til sitt emne. Fremstillingen er blitt for snill, for innforstått og for intern. Bokverket som en helhet er svakt, mens delene er sterke: Verket er mindre enn summen av delene» $(4,5)$.

\section{Medisin og medisinere}

Jeg har gått igjennom de ni bindene med særlig øye for hvordan Det medisinske fakultet og medisinere har kommet ut av det. Slagstad hevder at en «åpenbar styrke ved det nye verket er den sentrale plass som er gitt de naturvitenskapelige disipliner, inklusiv medisin. Det er et utvilsomt fremskritt i en historisk rekonstruksjon hvor de humanistiske fag har hatt hegemoniet» (3). At medisinen er tatt inn i varmen i dette verket er en interessant påstand. Hvordan har det seg at vi har stått utenfor? Det var nok ikke slik til å begynne med. 1800-tallets Christiania var preget av små forhold, og de få akademikerne som fantes, trengte nok å spille sammen. Noe av grunntanken bak Det Kongelige Frederiks Universitet var jo å utdanne landets egne embetsmenn. Men Slagstads beskrivelse er nok tref-

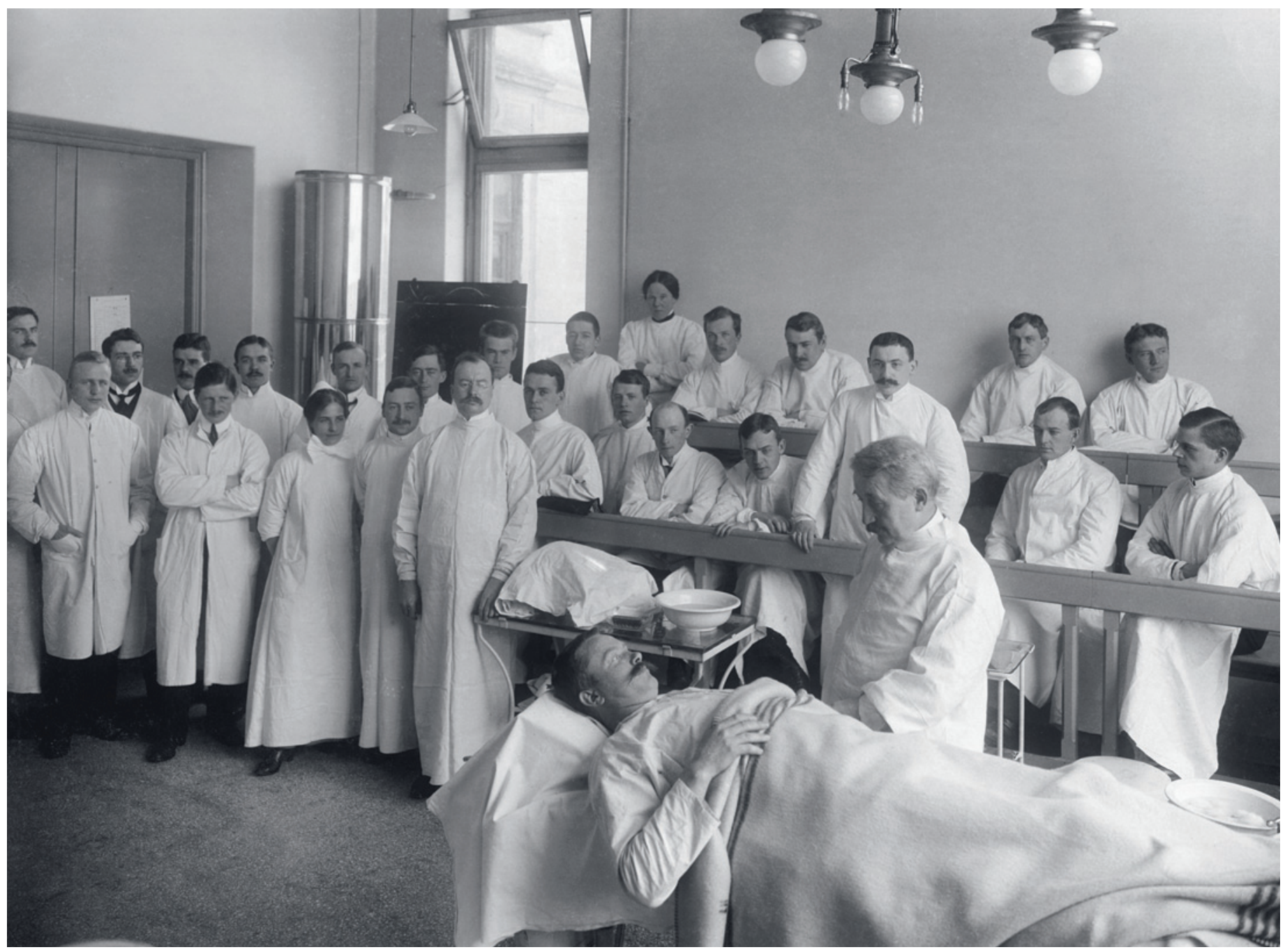

Kirurgiundervisning ca. 1910 med professor Hagbarth Strøm (1854-1912). Han var en av pionerene i norsk kirurgi og en av Tidsskriftets første redaktører. Strøm døde bare 57 år gammel, og i nekrologen het det at han i norsk medisin først og fremst hadde øvet innflytelse som lærer. Hans kliniske forelesninger var preget av «skarpsindighed, klarhed og nøgtern kritik». Som lege ble han «sit tilknappede og stundom noget afvisende væsen tiltrods omfattet med stor hengivenhed af de syge» (9). Fotografiet er gjengitt på omslaget av bind 2 av universitetshistorien. Foto Rude \& Hilfling, Oslo museum 
fende for de senere årtier. En forklaring er at poetokratiet har dominert historiefremstillingene, fordi de har skrevet dem selv. Historikere skriver historien. Om historikere. Hvem kjenner ikke Munch, Sars, Koht og Seip? Men hvem kjenner vel Birkeland, Bjerknes, Hassel og Owren? Men det er også andre forklaringer, f.eks. i måten fakultetet er bygd opp på. Medisinerne er plassert $i$ armlengdes avstand fra akademikernes hovedbøle på Blindern. Bygningene er i periferien: De basalmedisinske fagene holder til på Gaustad, universitetsklinikkene på Gaustad, Ullevål, Aker, Vinderen og andre steder. Oppfatningen av medisinere som håndverkere og annenrangs akademikere er rotfestet. Jeg tenker på det når jeg sykler gjennom universitetsområdet på Blindern. Jeg har aldri hatt noe fellesskap her, det var et sted vi som medisinstudenter ikke hadde noe forhold til. Vi dro dit en sjelden gang for å ordne praktiske ting, som semesterkort og legebesøk. Vi var fremmede, og slik er det fremdeles. Når jeg nå for tiden stikker innom det nye universitetsbiblioteket, Georg Sverdrups hus, kan jeg glede meg over det vakre bygget og de rike samlingene, men ordentlig mitt er det ikke.

Men også i vårt fag har vi selvsagt hatt kjemper som rager opp blant de fremste. På universitetsplassen i sentrum står to statuer av juristen Anton Martin Schweigaard (1808-70) og historikeren Peter Andreas Munch (1810-63). Gjennom den nye universitetshistorien blir vi minnet om at det skulle ha vært to til: av naturvitenskapsmannen Christopher Hansteen (1784-1873) og medisineren Frederik Holst (1791-1871) (3).

De seks første bindene er kronologiske gjennomganger av de 200 årene (ramme 1). Fremstillingene virker velskrevne og velinformerte. Jeg har kun sett enkelte upresise formuleringer. Om f.eks. Asbjørn Følling (1888-1973) står det at han «arbeidet som professor i fysiologi på Rikshospitalet» da han fikk besøk av en mor med to mentalt retarderte barn i 1934 (bd. 3, s. 182). Det var starten på historien om det vi kjenner som Føllings sykdom eller fenylketonuri. Men på dette tidspunktet var ikke Følling professor i fysiologi. Han arbeidet som professor ved det nyetablerte Throne-Holsts institutt for ernæringsforskning ved universitetet. Dette var riktignok plassert i 4. etasje i det medisinske bygget på Rikshospitalet (6), men det var ikke før i 1955 at han ble professor ved Rikshospitalet, og da ikke i fysiologi, men i biokjemi. Føllings karriere var uvanlig på mange måter. En annen detalj finner jeg i fremstillingen av Medisinske tidsskrifter (bd. 3, s. 197). Forfatteren omtaler kun Tidsskrift for Den norske laegeforening, men i perioden 1911-40, som er tema for bind 3, var det i tillegg to andre viktige generelle medisinske tidsskrifter i Norge: Norsk Magazin for Lagevidenskaben og Medicinsk Revue. De gikk inn i Nordisk Medicin i 1939. Litt pussig er det også at historien om universitetet under den annen verdenskrig (bd. 4) nærmest er et opptrykk av boken som ble publisert i 2007 (7).

\section{Den nære historien}

Jeg begynte ved Universitetet i Oslo høsten 1990. Det falt sammen med den mest dramatiske indre konflikten i universitetets historie i fredstid. Den relativt ferske universitetsdirektøren Kjell Stahl valgte å fratre sin stilling, skjønt noe valg hadde han vel i grunnen ikke, og rektor Inge Lønning ble langtidssykmeldt. Universitetet var en hårsbredd fra å bli satt under offentlig administrasjon. Denne lammende konflikten var forbundet med Lønning og Stahls forsøk

\section{Ramme 1}

\section{Bokverket Universitetet i Oslo 1811-2011:}

- Bind 1: John Peter Collett. Universitetet i nasjonen, 1811-1870

- Bind 2: Jon R. Kyllingstad og Thor Inge Rørvik. Vitenskapens univers, 1870-1911

- Bind 3: Jorunn Sem Fure. Inn i forskningsalderen, 1911-1940

- Bind 4: Jorunn Sem Fure. Universitetet i kamp, 1940-1945

- Bind 5: Fredrik W. Thue og Kim G. Helsvig. Den store transformasjonen, 1945-1970

- Bind 6: Kim G. Helsvig. Mot en ny samfunnskontrakt, 1975-2011

- Bind 7: Eirin Larsen, Peder Anker, Bent Sofus Tranøy, Magnus Gulbrandsen og Johannes W. Løvhaug. Samtidshistoriske perspektiver

- Bind 8: Jan Eivind Myhre. Kunnskapsbærerne 1811-2011, Akademikere mellom universitet og samfunn

- Bind 9: Tor Ivar Hansen (red.). Studentminner

på å innføre såkalt virksomhetsplanlegging og målstyring ved universitetet (bd. 6, s. 49). Striden fra den gang er fremdeles aktuell, ikke fordi saken fortsatt kaster skygger (8), men fordi byråkratiseringen $\mathrm{i}$ dag ligger som en klam hånd over universitetet.

Fremstillingen av stoffet er avdempet, og jeg synes det kler verket godt. Da Norges forskningsråd valgte de 13 første sentrene for fremragende forskning i 2002, uttalte to medisinere seg i sakens anledning. Kaare R. Norum, nylig avgått rektor, kalte det for en skandale, mens Lars Walløe mente at det var tatt «så mange geografiske, forskningspolitiske og økonomiske hensyn, at vi ikke på noen måte sitter igjen med Norges 13 fremste forskningsmiljøer». Til dette kommenterer historikeren tørt: «Selv om enkelte meget godt kvalifiserte miljøer ble refusert, kan imidlertid denne kritikken synes å være noe overdrevet» (bd. 6, s. 146).

En universitetshistorie i ni bind vil ikke pryde bokhyllene i særlig mange hjem. Det er like fullt grunn til å glede seg over den.

\section{Erlend Hem}

erlend.hem@medisin.uio.no

Tidsskriftet

Litteratur

1. Eriksen TB. Kunnskap og strid i 200 år. Aftenposten 19.10.2011: 10-1.

2. Eriksen TB. Feiring av kunnskapssamfunnet. Aftenposten 28.11.2011. www.aftenposten.no/kultur/litteratur/Feiring-av-kunnskapssamfunnet6708739.html (1.7.2012).

3. Slagstad R. Universitetshistorien - et førsteutkast. Klassekampen 4.11.2011. www.klassekampen.no/59518/article/item/null/universitetshistorien--et-forsteutkast (1.7.2012)

4. Søbye E. Når ambisjon møter realitet. Morgenbladet 21.10.2011. http:// morgenbladet.no/boker/2011/nar_ambisjon_moter_realitet (1.7.2012).

5. Søbye E. Når ambisjon møter realitet, del 2. Morgenbladet 28.10.2011. http:// morgenbladet.no/boker/2011/nar ambisjon moter realitet del 2 (1.7.2012). Lie SO. Føllings sykdom. Tidsskr Nor Lægeforen 2000; 120: 3042-3.

7. Hem E. Krigen på universitetet. Anmeldelse av: Fure JS. Universitetet i kamp 1940-1945. Tidsskr Nor Legeforen 2008; 128: 741.

8. Toft M. Knefall for Stahl? Uniforum 12.5.2011. www.uniforum.uio.no/meiner/ 2011/knefall-for-stahl.html (1.7.2012)

. Det norske medicinske selskab. Aftenposten (morgenutgave) 11.4.1912: 1 